\title{
Questes
}

\section{Éléments bibliographiques}

\section{(2) OpenEdition}

1 Journals

Édition électronique

URL : https://journals.openedition.org/questes/5762

DOI : 10.4000/questes.5762

ISSN : 2109-9472

Éditeur

Les Amis de Questes

\section{Édition imprimée}

Date de publication : 28 janvier 2021

Pagination : 145-146

ISSN : 2102-7188

\section{Référence électronique}

«Éléments bibliographiques », Questes [En ligne], 42 | 2021, mis en ligne le 28 février 2021, consulté le 06 février 2022. URL : http://journals.openedition.org/questes/5762 ; DOI : https://doi.org/10.4000/ questes. 5762 


\section{Éléments bibliographiques}

ARLINGHAUS, Franz-Joseph, Inklusion - Exklusion. Funktion und Formen des Rechts in der spätmittelalterlichen Stadt. Das Beispiel Köln, Köln/Weimar/Wien, Böhlau, 2018, p. 177-196.

BENVENISTE, Émile, «La blasphémie et l'euphémie », Problèmes de linguistique générale [1966], Paris, Gallimard, coll. « Tel», t. 2, 1974, p. 254-257.

-, Le vocabulaire des institutions indo-européennes, Paris, Les Éditions de Minuit, 1969.

BENYEKHLEF, Karim, Une possible histoire de la norme : les normativités émergentes de la mondialisation, Montréal, Thémis, 2008.

BOURDIEU, Pierre, «Le capital social. Notes provisoires », Actes de la recherche en sciences sociales, $\mathrm{n}^{\circ}$ 31, Paris, Les Éditions de Minuit, 1980, p. 2-3.

-, Ce que parler veut dire, Paris, Fayard, 1982.

CERQUIGLINI-TOULET, Jacqueline, «Fama et les preux : nom et renom à la fin du Moyen Âge », Médiévales, n² 24, 1993, p. 35-44.

CHAUVIN, Pierre-Marie, « La sociologie des réputations. Une définition et cinq questions », Communications, vol. 93, n² 2, 2013, p. 131-145.

DUTOUR, Thierry, Sous l'empire du bien : «Bonnes gens » et pacte social (XIII ${ }^{e}-X V^{e}$ siècle), Paris, Classiques Garnier, coll. «Bibliothèque d'histoire médiévale », 2015.

Fama, the politics of talks and reputation in Medieval Europe, dir. Thelma Fester et Daniel Lord Smail, Ithaca, London, Cornell University Press, 2003.

FLORI, Jean, «Aristocratie et valeurs chevaleresques dans la seconde moitié du XII ${ }^{\mathrm{e}}$ siècle : l'exemple des lais de Marie de France », Le Moyen Âge, vol. 96, 1990, p. 35-65.

GAUVARD, Claude, « La Fama, une parole fondatrice », Médiévales, n 24, 1993, p. 5-13.

GRONDEUX, Anne, «Le vocabulaire latin de la renommée au Moyen Âge », Médiévales, $\mathrm{n}^{\circ} 24,1993$, p. 15-26. 
HARDIE, Philip, Representations of Fama in Western Literature, Cambridge, Cambridge University Press, 2012.

HUIZINGA, Johan, L'automne du Moyen Âge [1932], trad. Julia Bastin, Paris, Payot, 2002.

LUPOI, Maurizio, The Origins of the European Legal Order [1994], Cambridge, Cambridge University Press, 2000.

MINOIS, George, Histoire de la célébrité, les trompettes de la renommée, Paris, Perrin, 2012.

POLSBY, Nelson, Community Power and Political Theory, New Haven, Yale University Press, 1963.

PORTEAU-BITKER, Annick, et TALAZAC-LAURENT, Annie, «La renommée dans le droit pénal laïque du XIII ${ }^{\mathrm{e}}$ au XV $\mathrm{XV}^{\mathrm{e}}$ siècle », Médiévales, $\mathrm{n}^{\circ} 24,1993$, p. 67-80.

THÉRY, Julien, «Fama: l'opinion publique comme preuve judiciaire. Aperçu sur la révolution médiévale de l'inquisitoire ( $\mathrm{XII}^{\mathrm{e}}-\mathrm{XIV}^{\mathrm{e}}$ siècles) », dans La preuve en justice de l'Antiquité à nos jours, dir. Bruno Lemesle, Rennes, Presses universitaires de Rennes, 2003, p. 119-147.

VAN CAENEGEM, Raoul C., «La Preuve dans le droit du Moyen Âge occidental. Rapport de synthèse », dans La Preuve. Deuxième partie: Moyen Âge et temps modernes, Bruxelles, Éditions de la Librairie encyclopédique, coll. «Recueils de la société Jean Bodin pour l'histoire comparative des institutions », vol. 17, 1965, p. 701-702. 